\title{
Design of PLC Based Automated Food Processing Machine
}

\author{
Vidya S Rao ${ }^{1}$, Praveen Shenoy K ${ }^{2}$, Santhosh K V*1 \\ ${ }^{1}$ Department of Instrumentation and Control Engineering, Manipal Institute of Technology, \\ Manipal Academy of Higher Education, Manipal, India \\ ${ }^{2}$ Department of Mechatronics Engineering, Mangalore Institute of Technology \& Engineering, \\ Moodabidri, Mangalore, India
}

Received: August 18, 2020. Revised: January 16, 2021. Accepted: February 8, 2021. Published: February 12, 2021.

\begin{abstract}
Ever-changing work expects technological advancement in all the tasks carried out by humans. Cooking is one such process, which is presently majorly carried out by human beings. Though a lot of automation has been happening in the area of food processing, involving a larger quantity of food production in a commercial or institutional setup. But very less automation is adapted in domestic or household cooking. In the proposed work, we propose to manufacture a system involving computers and electro-mechanical components for cooking two of the most widely consumed Indian delicacies Dosa (Pancake) and Idli (Rice cake). Reported work discusses the detailed mechanical fabrication of the device, including the process of automation implemented on Programmable Logic Controller (PLC). A detailed comparison is tabulated comparing the similar product to highlight the working of the proposed system.
\end{abstract}

Keywords - Automation, Food processing, Dosa maker, Idli maker, Programmable Logic Controller

\section{INTRODUCTION}

$\mathrm{T}$ HE smart kitchens are home automation projects where combined mechanics, electronics, and smart solutions are incorporated to simplify the pre-existing procedures involved in cooking. Currently, due to increasing access to the internet and the development of domestic technology, digital is integrated into several household appliances and home items which makes the system a lot simpler. These structural solutions are currently needed at the household level to reduce the substantial amount of time being spent in the kitchen on daily basis. The "PLC based automated food processing machine" which is described in detail in the further sections, specifically related to the automatic preparation of dosa and idli in particular by the use of dedicated mechanisms and how those mechanisms are integrated to make the overall process of preparation of food items without any human intervention.

A device capable of producing 1000/1200 idlis/hour has been developed by Central Food Technological Research Institute India (CFTRI), Mysore which aims at large-scale production of idlis [1]. The device has been later modified accordingly to dispense a pre-determined amount of batter from the reservoir tank into the moving idli pans at the feeding unit [2]. A device comprising of an assembly for scraping, rolling, and discharging the dosa has been developed by CFTRI, Mysore [3]. Only a part of the procedure involved in food processing is automated. In most of the devices related to food processing, a relay triggering circuit has been used to actuate all the electromechanical components connected either to a single-phase source or three-phase source [4].

In all the above-mentioned devices relayed to preparation of idli and dosa, batter needs to be prepared separately. In some cases, the size of the device is not convenient, and the price of the device is not affordable for domestic use, hence making those devices suitable only for industrial large-scale production by using relays and programmable controllers [5], [6]. Various automation techniques used in food processing are discussed in available literature [7]. The design of a rubber gripper which can grasp different types of food products used in the food of food manufacturing is reported in [8]. Paper [9], presents a method of selection of industrial robots for the manufacturing of food products. Implementation of robots for carrying out functions in a food production facility is reported in [10]. Several aspects of technology interferences on to the food industry are reported in detail in [11]. The use of advanced technologies in food processing industries are reported in [12].

From the consumer point of view, a device that is compact 
and cost-effective, which has a provision for preparation of dosa or idli or both dosa and idli would prove to be beneficial for commercial and small-scale preparation for a nuclear family. It is thus an objective to develop a compact and convenient device that would automate the process of preparation of dosa, right from grinding the raw material to automatically scraping of dosas or steaming the batter into idlis. The device discussed throughout the sections focuses on the usage of different drivers, motors, and actuating techniques that can be applied to the field of food processing through hardware and programming techniques [13-17].

Equipment effectiveness is an indicator of the health of automation in the food processing industry which will further determine the effectiveness of the system, a discussion of the same is reported in [18]. Implementation of smart factory architecture of horizontal manufacturing in a cheese factory is reported in [19]. Paper [20], reports the use of robots and autonomous systems in the food industry for supply chain management. Image processing tools are used to counted and verify the sizes of olive seeds in [21]. Analysis of food quality based on smart contracts and evaluation model is reported in [22]. Different types of sensor design used in the food processing industry to monitor the quality of food products is reported in [23]. Fabrication of equipment using sustainable technologies for carrying out tasks related to food processing is discussed in [24]. Diary plant model is analyzed for thermal and exergoeconomic conditions under varying conditions of the productivity cycle in [25]. Automated manufacturing execution system implementation in the beverage industry is discussed in [26]. Implementation of a model predictive control strategy for enhancement of operational reliability in the beverage industry is reported in [27].

From the above literature, it is clear that though few applications are reported for the preparation of food products. But these processes are not fully automated, and these solve the problems at large scale manufacturing. Because of the above reason, the work proposes a design of fully automated smart equipment which is a small scale model that can be used by a small family in their kitchen.

\section{MATERIALS AND METHODS}

The design and development of the prototype is based on an Iterative design procedure involving a cyclic process of designing, prototyping, testing, analyzing, and refining the product. The various phases of development involve conceptual design, preliminary design, and complete design, fabricating and testing the prototype.

\section{A. Electrical and Electronic components}

\begin{tabular}{lll}
\hline Component & $\begin{array}{l}\text { Use in Implementation } \\
\text { of Prototype }\end{array}$ & Specifications \\
\hline
\end{tabular}

\begin{tabular}{|c|c|c|}
\hline $\begin{array}{l}\text { Mixer- } \\
\text { Grinder }\end{array}$ & $\begin{array}{l}\text { Transforms the raw } \\
\text { materials into batter and } \\
\text { dispenses the batter into a } \\
\text { container }\end{array}$ & $\begin{array}{l}\text { Manufacturer: Bajaj Motor } \\
\text { Rating: 500W Jar Capacity: } \\
\text { 1.5L Rated Voltage: } 230 \mathrm{~V}\end{array}$ \\
\hline $\begin{array}{l}\text { Induction } \\
\text { heater }\end{array}$ & $\begin{array}{l}\text { The induction heaters are } \\
\text { used to heat the hotplate in } \\
\text { the dosa maker } \\
\text { subassembly as well as the } \\
\text { utensil in the idli maker } \\
\text { subassembly. }\end{array}$ & $\begin{array}{l}\text { Manufacturer: Sheffield } \\
\text { Classic Power Input: 230V, } \\
50 \mathrm{~Hz} \text { Power Consumption: } \\
1500 \mathrm{~W}\end{array}$ \\
\hline \multirow[t]{2}{*}{$\begin{array}{l}\text { Stepper } \\
\text { Motor }\end{array}$} & \multirow{2}{*}{$\begin{array}{l}\text { The stepper motor is used } \\
\text { to rotate the idli plates in } \\
\text { steps of } 90 \text { degrees at a } \\
\text { time, to fill the } \\
\text { containments with batter. }\end{array}$} & \multirow{2}{*}{$\begin{array}{l}\text { Type: Hybrid Stepper motor } \\
\text { Rated Voltage: } 12 \mathrm{~V} \text { DC } \\
\text { Rated current: } 0.4 \mathrm{~A} \\
\text { No of Phase: } 2 \text { Step } \\
\text { Angle: } 1.8^{\circ} \text { Mass: } 0.2 \mathrm{Kg}\end{array}$} \\
\hline & & \\
\hline $\begin{array}{l}\text { TB6600 } \\
\text { Stepper } \\
\text { Driver }\end{array}$ & $\begin{array}{l}\text { Used to command the } \\
\text { Stepper motor through } \\
\text { PWM input. }\end{array}$ & $\begin{array}{llr}\text { Input current: } 0-5 \text { A } & \mathrm{O} / \mathrm{P} \\
\text { current: } 0.5 \text { to } 4 & \mathrm{~A} \\
\text { Power(max): } 160 & \mathrm{~W} \\
\text { SupplyVoltage: } 9 \text { to } 42 & \mathrm{~V} \\
\text { Logic Voltage: } 3.3 \text { to } 5 \mathrm{~V} \text {; } \\
\text { Logic current: } 8 \text { to } 15 \mathrm{~mA}\end{array}$ \\
\hline LM7805 IC & $\begin{array}{l}\text { LM7805 Voltage regulator } \\
\text { circuit is used to limit the } \\
\text { logical input to TB6600 } \\
\text { stepper motor driver. }\end{array}$ & $\begin{array}{l}\text { Input Voltage; } 7 \text { to } 35 \mathrm{~V} \\
\text { Regulated Output: } 4.8 \mathrm{~V} \text { to } \\
5.2 \mathrm{~V}\end{array}$ \\
\hline $\begin{array}{l}\text { Motorized } \\
\text { Ball Valve }\end{array}$ & $\begin{array}{l}\text { Motorized ball valves are } \\
\text { used to dispense a } \\
\text { predetermined amount of } \\
\text { batter to subassemblies. }\end{array}$ & $\begin{array}{l}\text { Pressure:0 to } 1 \mathrm{MPa} \text { Voltage: } \\
12 \mathrm{~V} \text { DC Power: } 4 \mathrm{~W}(\max ) \\
\text { Current; } 60 \text { to } 80 \mathrm{~mA} \text { Nominal } \\
\text { Size: DN20 }\end{array}$ \\
\hline \multirow[t]{2}{*}{$\begin{array}{l}\text { Synchronou } \\
\text { s Motor }\end{array}$} & \multirow[t]{2}{*}{$\begin{array}{l}\text { Used to rotate the hot- } \\
\text { plate in clockwise/counter- } \\
\text { clockwise direction }\end{array}$} & $\begin{array}{l}\text { Voltage: } 208 \text { to } 230 / 240 \mathrm{~V} \\
\text { Output Power: } 14 \mathrm{~W} \\
\text { Frequency: } 50 \text { to } 60 \mathrm{~Hz} \text { Phase: } \\
\text { Single Phase }\end{array}$ \\
\hline & & $\begin{array}{l}\text { Model Type: } 60 \mathrm{KTYZ} \\
\text { Permanent magnet geared } \\
\text { synchronous motor }\end{array}$ \\
\hline \multirow{3}{*}{$\begin{array}{l}\text { PLA MCC- } \\
\text { 2C } \\
\text { Relay }\end{array}$} & \multirow{3}{*}{$\begin{array}{l}\text { PLA MCC two-channel re- } \\
\text { lays are used to control the } \\
\text { switching of all electro- } \\
\text { mechanical components }\end{array}$} & $\begin{array}{l}\text { Contact Material: Silver Alloy } \\
\text { Operate time: } 0.02 \mathrm{~s}\end{array}$ \\
\hline & & $\begin{array}{l}\text { Release time: } 0.01 \mathrm{~s} \text { Nominal } \\
\text { Voltage: } 24 \mathrm{~V} \text { Impulse: } 5 \mathrm{kV}\end{array}$ \\
\hline & & $\begin{array}{ll}\text { Life expectancy: } & 106 \\
\text { operations at rated load } & \end{array}$ \\
\hline \multirow{4}{*}{$\begin{array}{l}\text { Delta } \\
\text { DVP16ES20 } \\
\text { OR PLC }\end{array}$} & \multirow{4}{*}{$\begin{array}{l}\text { Controls switching of all } \\
\text { the electromechanical } \\
\text { components }\end{array}$} & No of Inputs: 8 \\
\hline & & Program capacity: $16 \mathrm{k}$ steps \\
\hline & & $\begin{array}{l}\text { COM ports: } 1 \text { RS- } 232 \text { port } \\
\text { and }\end{array}$ \\
\hline & & 2 RS-485 ports \\
\hline
\end{tabular}

\section{B. Development of Final Prototype}

The structural framework of the prototype is built from teak wood spanning a length of 25 inches, width of 15 inches, and height of 20 inches.

As a first step in the process, raw materials need to ground and transformed into batter. Mixer-Grinder unit is used to transform the raw materials into batter and for this purpose, a motorized ball valve is welded to the lowermost part of the jar of the mixer-grinder to dispense the batter into the storage container. The way a motorized ball valve is fitted to the jar of the mixer grinder can be seen in Fig. 1. 


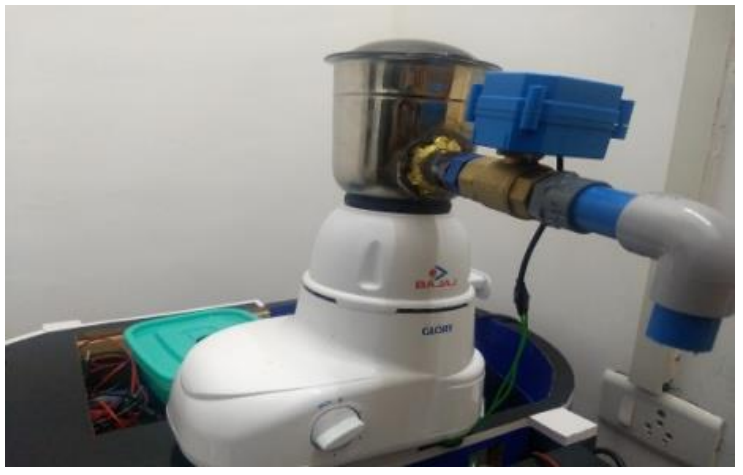

Fig. 1. Mixer-Grinder with Motorized Valve

\section{Idli Maker Subassembly}

The induction heater is used to heat the water and transform it into steam to cook the batter into idlis. An opening of diameter three fourth of an inch is made through both ends of the induction heater passing through its center. This is done using drilling operation on lathe. A shaft with threads on its top-end passes through this opening. An idli plate is secured on the threaded end of this shaft by a hex-nut.

The idli cooker and idli plates are made of stainless steel. An idli plate having four containments each is placed within the idli cooker by screwing it to the threaded shaft. The idli plate rests on top of the hex-nut screwed to one end of the shaft. The shaft passes through an opening made through the center of the base of the idli cooker. The threaded shaft is coupled to the shaft of the stepper motor by tolerance fit. A stainless-steel profile having a through-all hole of half-inch is welded to the center of the base of the idli cooker so that water may be filled up to the height of this particular profile. Since the stainless-steel profile is welded to the center of the base of the idli cooker, it prevents any discharge of water through the hole through which the shaft goes through. The idli maker subassembly has been shown in Fig. 2.

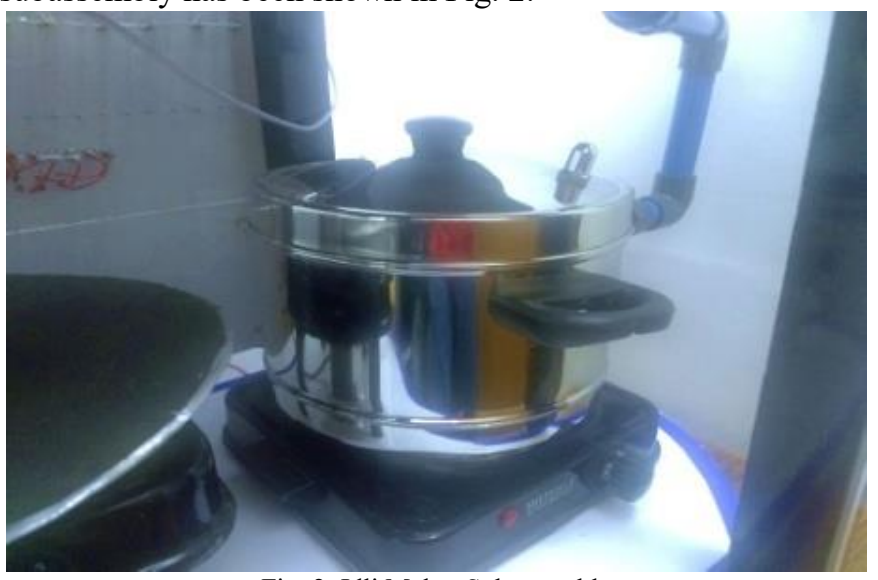

Fig. 2. Idli Maker Subassembly

A hollow shaft stepper motor rotates the idli plates by 90 degrees at a time to fill a particular containment with batter which flows through the motorized ball valve. This process of filling the containment with batter continues until all four containment are filled. Filling of the containment with batter is controlled by timers through the PLC [14], [15].
The stepper motor is controlled by a TB6600 stepper driver [16] which is commanded through PWM input by the PLC. The command from the PLC is given to a regulator circuit illustrated in Fig. 3. The output from the regulator circuit is given to the TB6600 stepper motor driver. The purpose of the regulator circuit is to regulate the logic voltage between 3.3 to $5 \mathrm{~V}$ and current between 8 to $15 \mathrm{~mA}$. Also, the stepper motor and the TB6600 stepper motor driver are shown in Fig. 4 and Fig. 5 respectively.

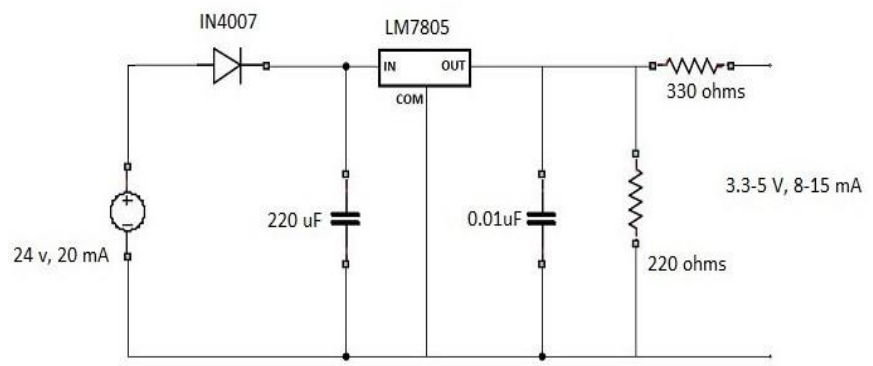

Fig. 3. Regulator circuit

A motorized ball valve is used to dispense the batter from the storage container into the containments of the idli plate. A similar valve is also used in Dosa Maker subassembly to dispense the batter from container to hotplate. The opening and closing of the valve are controlled by the PLC through a relay. The motorized ball valve used in the subassembly is shown in Fig. 6.

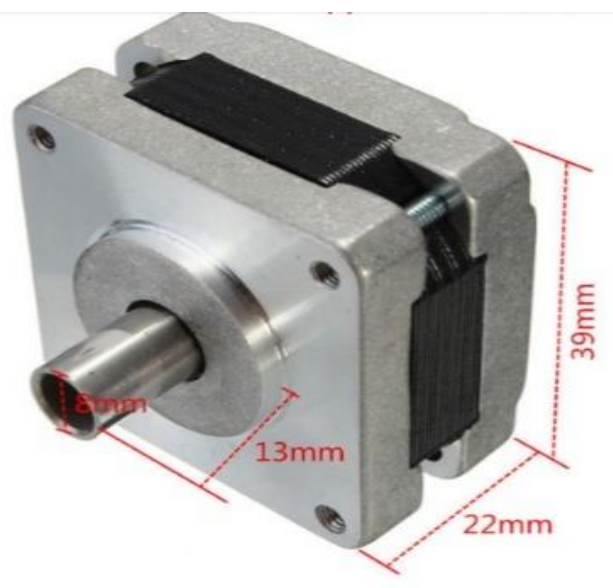

Fig. 4. Hollow shaft stepper motor

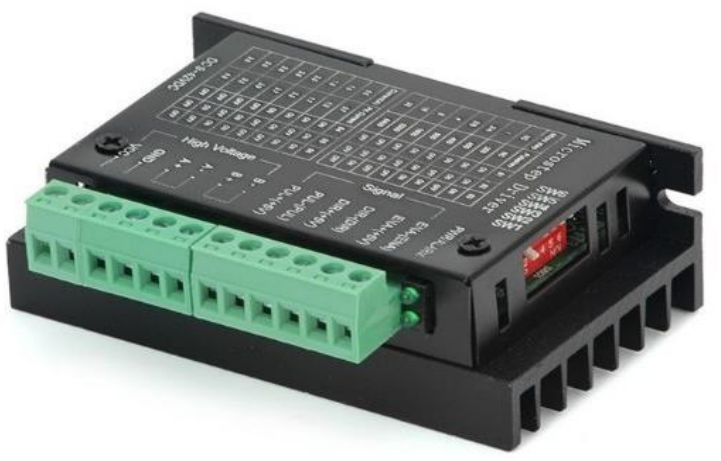

Fig. 5. TB6600 stepper motor driver 


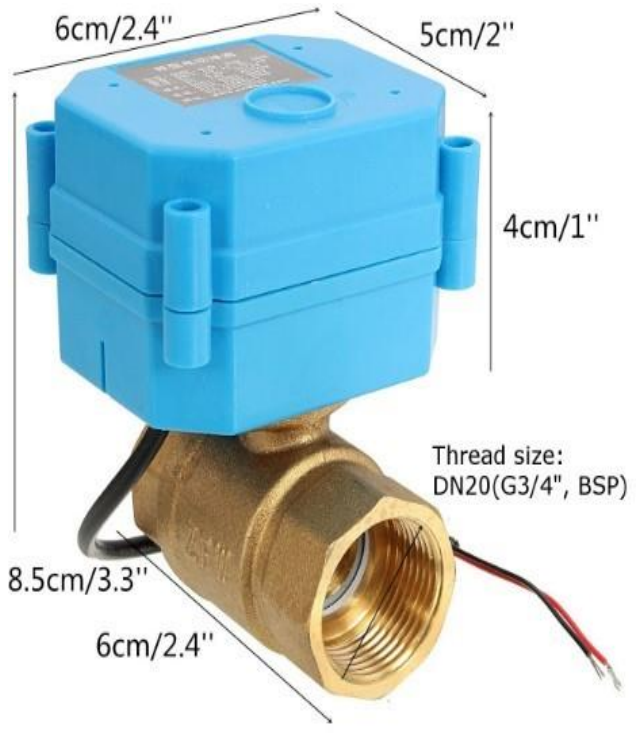

Fig. 6. Motorized ball valve

\section{Dosa Maker Subassembly}

An induction heater is used to heat the hot plate to cook the batter into dosa. An opening of a diameter of 1 inch is made through both ends of the induction heater passing through the center of the induction top plate. The shaft of the synchronous motor which is connected to the hot plate through a stainlesssteel rod, passes through this opening. The induction heater is firmly secured to the structural framework using fasteners.

The hot plate used in the subassembly is made-up of mild steel with a non-stick coating on the top. Also, the spreader and scraper attached to the structural framework are made of stainless steel. The heating of the hot plate is affected by the induction heater. The batter drops on top of the hot plate through a motorized ball valve situated right on top of the hot plate. The batter is spread into circular/elliptical formation by the spreader due to the rotation of the hot plate.

The thickness of the dosa is fixed as the clearance between the spreader and the hot plate is approximately $3 \mathrm{~mm}$. The dosa gets cooked as it moves on top of the hot plate in the clockwise direction. The scraper which is fixed to the left-hand side of the structural framework stays almost in contact with the hot plate. It moves in a clockwise direction. As the dosa comes in contact with the sharpened edge of the scraper, it will be slowly discharged onto a tray.

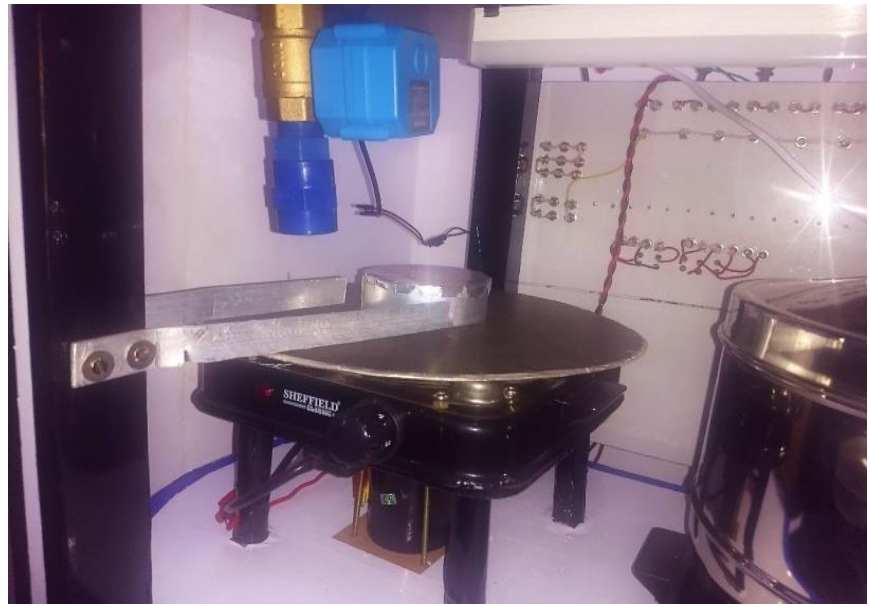

Fig. 7. Dosa Maker Subassembly

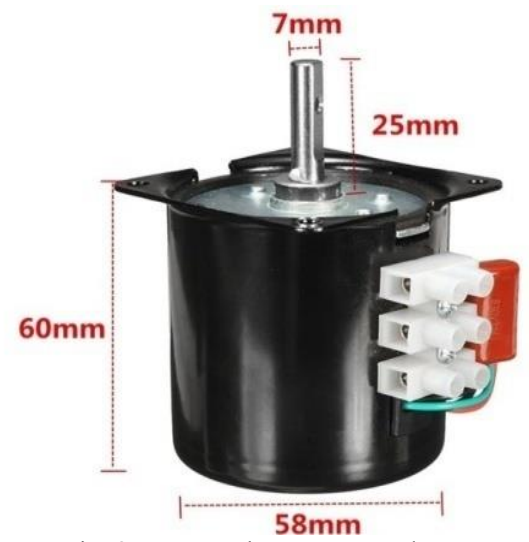

Fig. 8. AC synchronous geared motor

The synchronous geared motor is connected to the hot plate and rotates the hot plate in the clockwise direction. The shaft of the synchronous motor is extended by connecting it to a stainless-steel rod, by a key to secure it firmly. The said stainless steel rod is welded to a stainless steel plate which is connected to the hot plate by nut and bolt fasteners.

To avoid all the load being acting upon the shaft of the synchronous motor, stainless steel ball casters are secured in place on top of the induction heater. Four stainless-steel ball casters are secured at the 4 corners of the induction heater assembly, distribute the weight of the hot plate evenly, thus preventing any deflection of the shaft of the synchronous motor. Without the presence of the 4 stainless-steel ball casters, the shaft of the synchronous motor would be subjected to load which could have caused deflection after several iterations. Hence casters were used to minimize \& distribute this load evenly over the assembly. The Dosa Maker Subassembly has been shown in Fig. 7 and the synchronous motor used in the Dosa Maker subassembly has been shown in Fig. 8. The final prototype developed is as shown in Fig. 9. 


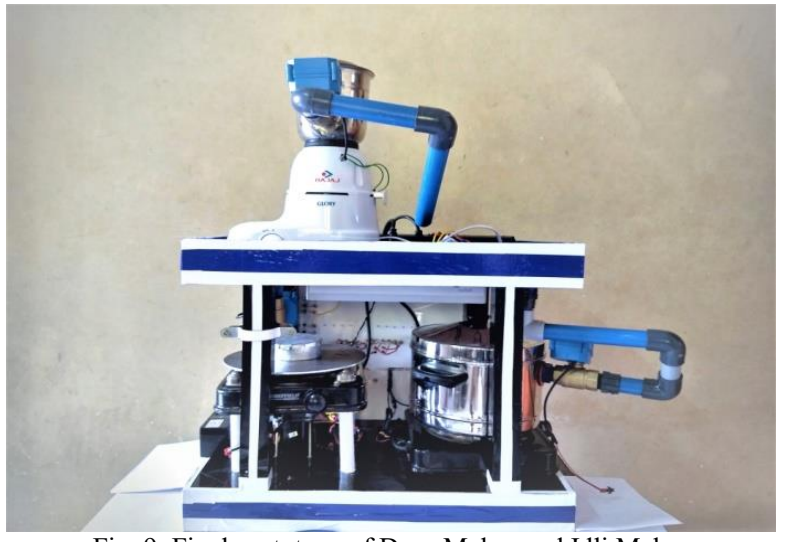

Fig. 9. Final prototype of Dosa Maker and Idli Maker

\section{Control Logic}

The prototype was operated on Delta DVP16ES200R Programmable Logic Controller (PLC) [28]. The Delta DVP16ES200R PLC is shown in Fig. 10. The electromechanical components were connected to the PLC through relays. The control circuit board is shown in Fig. 11

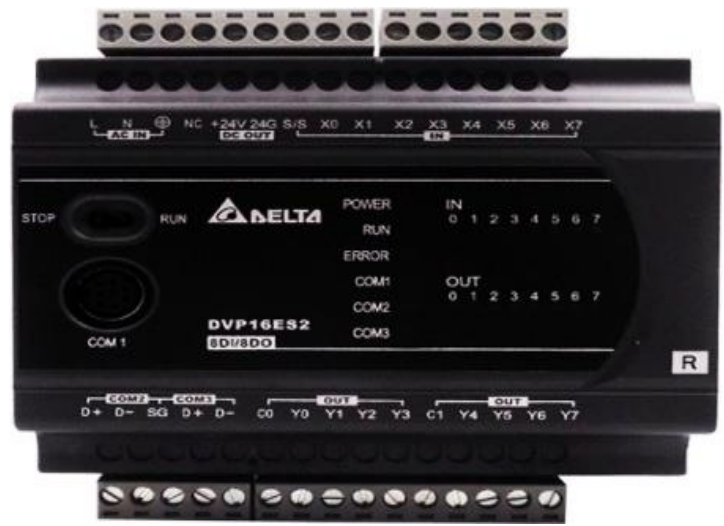

Fig. 10: Delta DVP16ES200R PLC

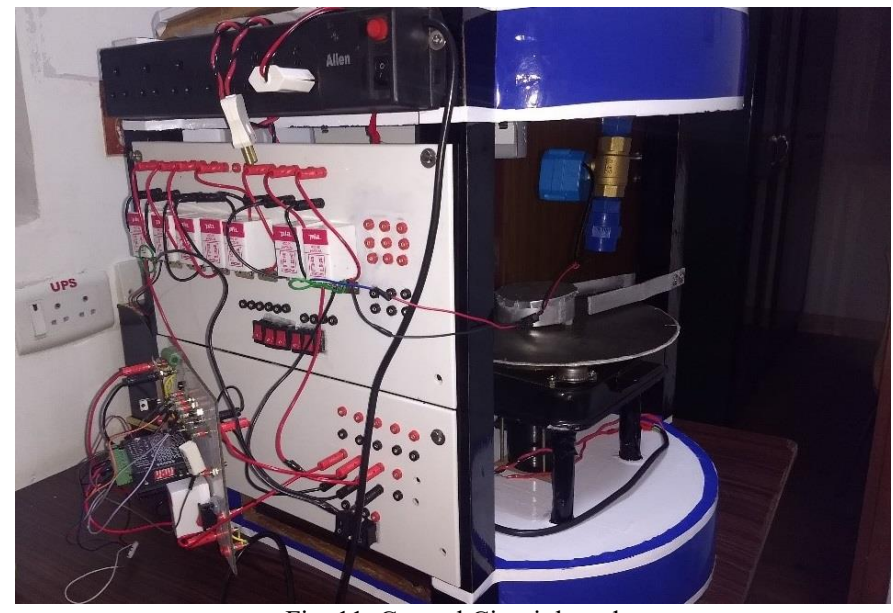

Fig. 11. Control Circuit board

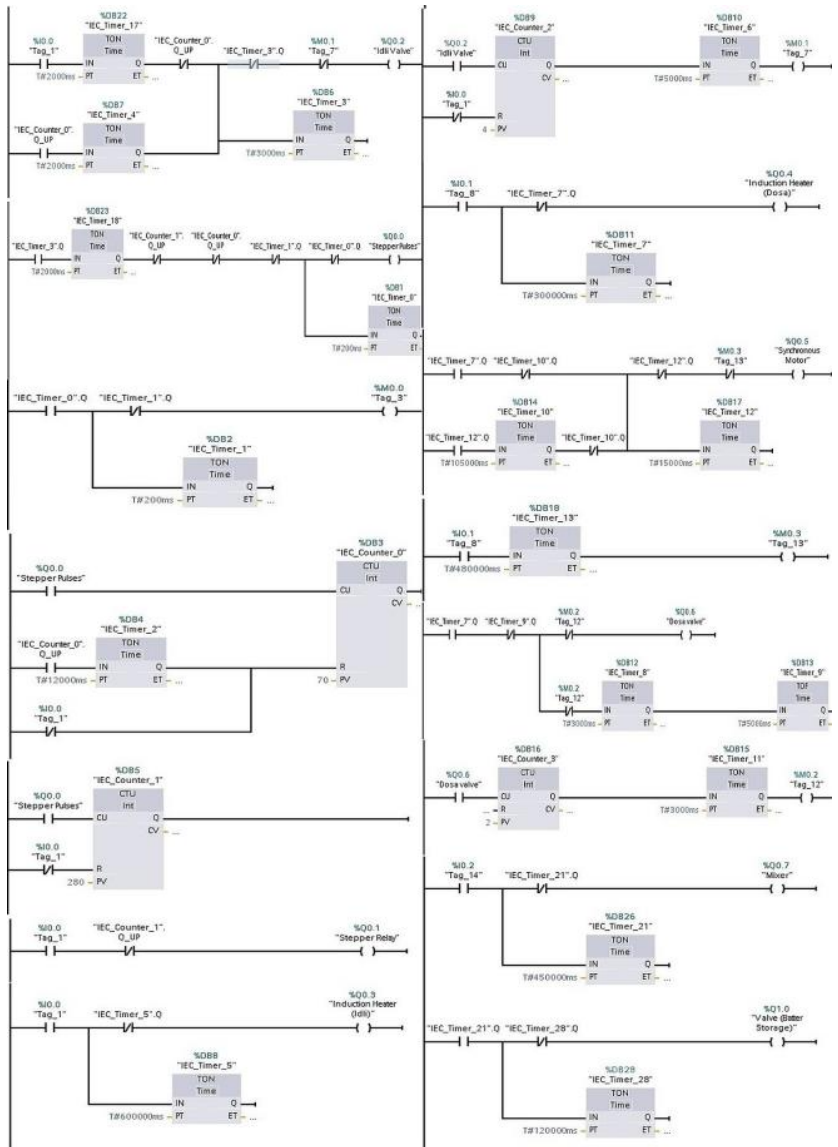

Fig. 12. Ladder Logic Programming using TIA Portal

The logical programming was done through Delta WPLSoft programming software. The ladder logic programming sequence modified for the prototype has been shown in Fig. 12.

\section{RESULTS}

After assembling all the mechanical components in the subassemblies, the Dosa and Idli Maker sub-assemblies were tested for their mode of working by using the Arduino Mega 2560 R3 controller. This was done to verify the conceptual framework upon which the assemblies were built before transferring the control to PLC. To evaluate new designs before the actual interfacing, it was important to ascertain that the designs were clear, easy to use, and meet the objective so that changes could be easily made often to ensure that major issues do not arise before interfacing the prototype with the PLC.

Except stepper motor, the rest of the electrical and electronic components could be easily configured on the PLC platform without any difficulties. The stepper motor was extremely challenging to configure due to a mismatch in voltage and current ratings between PLC and the stepper drivers. The UNL2003 driver used to drive the stepper motor in unipolar configuration couldn't be connected through PLC due to socket-size and voltage restrictions. Hence the stepper motor was configured in A4988 with command signals regulated through LM7805 IC. Even though the driver was 
able to receive command from the PLC and rotate the stepper motor, the fluctuation in the voltage as well as current levels failed the IC on multiple occasions. Therefore, the TB6600 micro-stepping driver was used to interface the stepper motor with PLC due to its robustness and reliability. To limit the logical voltage and current ratings as per the driver specification, the regulator circuit illustrated in Fig. 3 was used. This solved the problem of spikes in voltage and current levels. The main purpose of the regulator circuit was to regulate the logic voltage between 3.3 to $5 \mathrm{~V}$ and current between 8 to $15 \mathrm{~mA}$. The stepper motor was able to receive command pulses from PLC and rotate in the specified manner of steps. In the future, the prototype may be commercialized as listed below,

- By using metal-alloys for developing the structuralframework of the project.

- By using ISO standard pipes and connectors for dispensing batter.

The proposed prototype is a compact and cost-effective alternative to the commercially available variants which are capable of preparing just one specific delicacy. Here, the user is provided with an option to choose the preference as well as quantity of the delicacy/delicacies to be prepared which is certainly an added convenience. Being compact in size, the proposed prototype would require the least amount of mounting area, when it is commercialized. All these attributes would further advance the possibilities that can be conceptualized and implemented with the aid of automation in the field of food processing. The comparison of the prototype with two existing products has been given in Table 1.

Table 1. Comparison of proposed prototype with two existing techniques

\begin{tabular}{|l|c|c|c|}
\hline \multicolumn{1}{|c|}{ Parameter } & $\begin{array}{c}\text { CFTRI } \\
\text { Dosamaker }\end{array}$ & Dosamatic & $\begin{array}{c}\text { Proposed } \\
\text { Prototype }\end{array}$ \\
\hline Compact & No & Yes & Yes \\
\hline $\begin{array}{l}\text { Target } \\
\text { demographics }\end{array}$ & $\begin{array}{c}\text { Mass } \\
\text { in Bulk food } \\
\text { processing } \\
\text { units }\end{array}$ & $\begin{array}{c}\text { Small scale } \\
\text { production } \\
\text { in Hotels } \\
\text { and } \\
\text { Restaurants }\end{array}$ & $\begin{array}{c}\text { Nuclear } \\
\text { Family }\end{array}$ \\
\hline Supply Voltage & $440 \mathrm{~V}$ & $230 \mathrm{~V}$ & 230V \\
\hline $\begin{array}{l}\text { Delicacy that } \\
\text { can be prepared }\end{array}$ & Dosa & Dosa & $\begin{array}{c}\text { Idli and } \\
\text { Dosa }\end{array}$ \\
\hline $\begin{array}{l}\text { Cost- } \\
\text { Effectiveness } \\
\text { for domestic } \\
\text { family }\end{array}$ & Less & Less & More \\
\hline $\begin{array}{l}\text { Capacity } \\
\text { medium- }\end{array}$ & $\begin{array}{c}50 \text { Medium- } \\
\text { sized Dosas } \\
\text { per hour }\end{array}$ & $\begin{array}{c}\text { Dosas per } \\
\text { hour }\end{array}$ \\
\hline
\end{tabular}

\section{CONCLUSION}

The prototype was developed which completely automates the process of preparation of Dosa and Idli. The prototype was tested several times for proof of concept and all the trails are well documented. A novel approach was demonstrated using an iterative design procedure to develop sub-assemblies present in the prototype. Significant challenges in fixtures and electrical connections had to be suitably addressed to automate the process of preparation of dosa and idli. The prototype was developed using relays and PLC control scheme. The results clearly show the advantage of automation in food processing which saves a considerable amount of time and also provides novel techniques that have not been explored before. The proposed method of automation for the said delicacies can be further explored which can result in a considerable reduction in size and weight of the prototype. The device has the potential to be commercialized by using ISO standard components. The device would definitely ease the lifestyle of individuals, especially from nuclear families, by saving a considerable amount of time which the conventional method of preparation would require. It also has comparatively higher advantages over the techniques which are already there in the market which is tabulated in the results section.

\section{APPENDIX}

\section{Detailed Drawings of Prototype}

The "PLC Based Automated Food Processing Machine" is illustrated in the accompanying drawings throughout which, the reference letters indicate corresponding parts in various figures. As shown in Fig. A.1, the Dosa Maker subassembly (200) consists of a hot plate (201), keyed to the synchronous motor (205) using a stainless-steel rod (204) welded to a stainless-steel plate (207) and secured to a hotplate by rivets (208). The stainless-steel rod (204) is drilled on one end to match the shaft diameter of the synchronous motor (205) and is secured in place by a key (203). Stainless steel ball casters (212) are placed at the four corners of the induction heater (202) to support the weight of the hot plate (201). The induction heater (202) is provided with four legs (209) which is firmly attached to the rigid support base (109). A circular disc (208) made of aluminum is placed on top of the hotplate around the four rivets (208) securing the hot plate (201) on top of a steel plate (207). The hot plate (201) passes co-axially through the induction heater (202) and would rotate on top of the said induction heater wherein the heat would be transferred from the induction top plate (211) to the said hot plate (201). The temperature of the hot plate can be varied utilizing a knob (210) provided on the induction heater. 


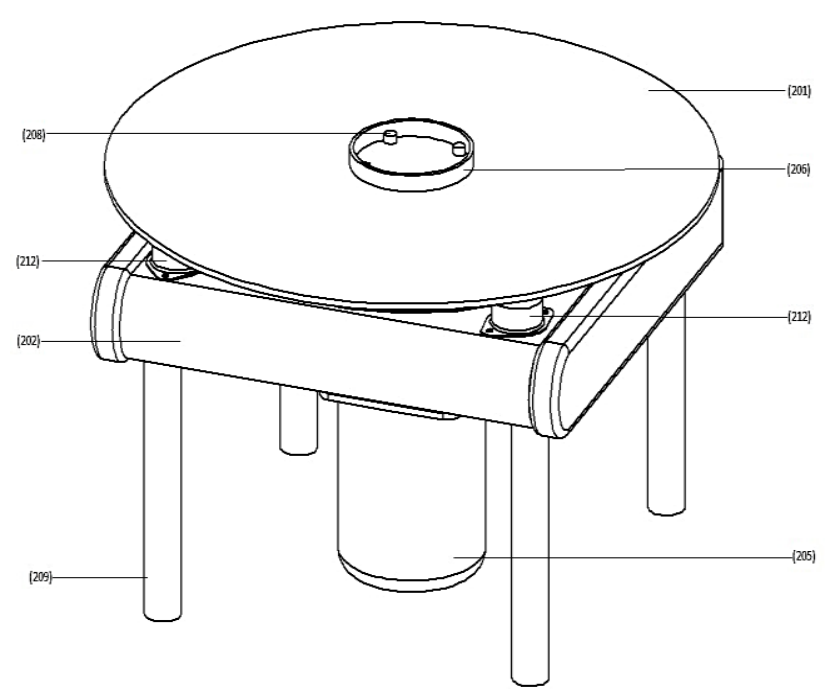

Fig. A.1. Dosa Maker Isometric View

As shown in Fig. A.2, the Idli Maker subassembly (300) consists of an idli cooker (301) placed on top of an induction heater (302), wherein the said idli cooker consists of two idli plates (309) having four idli containment (310) and resting its base on a hex-nut (312) screwed to a threaded shaft (308) and also firmly secured to the said threaded shaft by yet another hex-nut (312) on top of the said idli plate. The threaded shaft is coupled to the stepper motor (304) by a flexible coupling (303) by the virtue of which, the motion of the stepper motor shaft (305) is transferred to the said threaded shaft. The idli cooker $(301)$ has two openings $(306,307)$ for filling the batter into the containment of the two idli plates wherein the openings are sealed for any kind of pressure leakage by gasket. A stainless-steel profile is (311) is welded to the base of the idli cooker wherein water would be filled slightly below the height of the said stainless steel profile (311), within the said idli cooker.

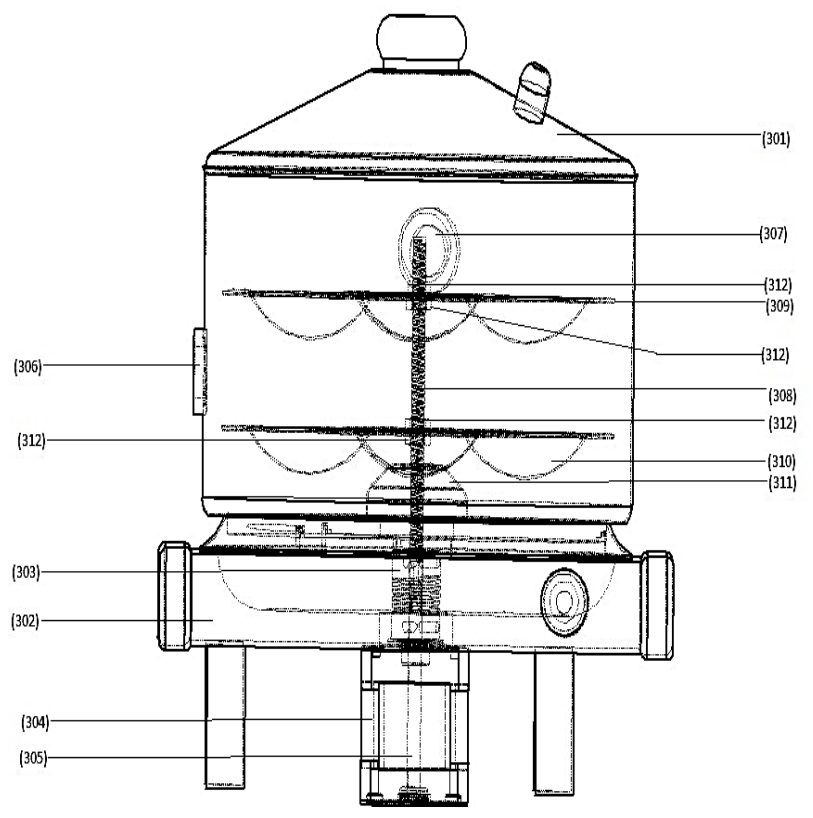

Fig. A.2. Idli Maker subassembly.

\section{PATENTS}

Indian patent has been filed on 29.11.2018 with the tracking number is 201841045058 with the invention title, "Automated Food Processing Machine Using Programmable Logic Controller" with Applicant as Manipal Academy of Higher education,

\section{Acknowledgment}

We would like to thank the Instrumentation and Control Engineering Department, Manipal Institute of Technology, Manipal Academy of Higher Education, Manipal, India for providing all the required laboratory facilities. We would also like to thank all the referees cited in this paper.

\section{References}

[1] K. Javaraiah, "A device useful for continuous dispensing of idli batter and like materials," India Patent 218 380, March 31, 2008.

[2] V.D. Nagaraju, "A device for continuous dispensing of idli batter," India Patent 223 011, September 02, 2008.

[3] K.V. Murthy. A device useful for automatic discharge of dosa and other similar Indian traditional foods. Patent IN 230948,02 28, 2009.

[4] Bhagirath Ghanshyambhai. Portable fully automatic cooking machine. Patent PCT WO2015075730A2, 07, 20, 2015.

[5] Chano. S. R, "Ancillary protective and control functions common to multiple protective relays," in Proc. 64th Annual Conference for Protective Relay Engineers, 2012.

[6] Sidhu T. S, "Bibliography of relay literature, 1994 IEEE Committee Report", IEEE Transactions on Power Delivery. Vol. 11, No. 3, pp. 1251-1262, 1994.

[7] Jingdun Jia, Donghong Liu, Haile Ma. Advances in Food Processing. Zhejiang University Press - Springer, 2019.

[8] Zhongkui Wang, Keung, Shinichi Hirai, "A Dual-mode Soft Gripper for Food Packaging," Robotics and Autonomous System, Vol. 125, pp. 103427, 2020.

[9] Farah Bader, Shahin Rahimifard, "A methodology for the selection of industrial robots in food handling," Innovative Food Science and Emerging Technologies, Vol. 64, pp. 102379, 2020.

[10] R. Accorsi, A. Tufano, A. Gallo, F. G. Galizia, G. Cocchi, M. Ronzoni, A. Abbate, R Manzini, "An application of collaborative robots in a food production facility, "presented at 29th International Conference on Flexible Automation and Intelligent Manufacturing (FAIM2019), June 24-28, 2019, Limerick, Ireland.

[11] Hannah Hamilton, Roslyn Henry, Mark Rounsevell, Dominic Moran, Frances Cossar, Kathleen Allen, Lisa Boden, Peter Alexander, "Exploring Global Food System Shocks, Scenarios and outcomes," Futures, Vol. 123, pp. 102601, 2020. 
[12] Janmenjoy Nayak, Kanithi Vakula, Paidi Dinesh, Bighnaraj Naik, Danilo Pelussi, "Intelligent food processing: Journal from artificial neural network to deep learning," Computer Science Review, Vol. 38, pp. 100297, 2020.

[13] Friend Fred, "Effect of Distribution Automation on Protective Relaying," in Proc. 67 $7^{\text {th }}$ Annual Conference for Protective Relay Engineers, 2015.

[14] Chao. He, "The innovation of relay-contactor controlled machine tools by PLC Techniques," in Proc. of $3^{\text {rd }}$ World congress on intelligent control and automation, 2002.

[15] Vesley. I, "MRAS identification of permanent magnet synchronous motor parameters," in Proc. $15^{\text {th }}$ IFAC Conference on Programmable devices and embedded systems, 2018.

[16] Bethoux. O, "An advanced control for PM synchronous motor drive in power graded mode," in Proc. International conference on emerging and renewable energy, 2017.

[17] Viaene De Jasper, "Load angle estimation for dynamic stepping motor," Mechatronics, Vol. 08, pp.229-240, 2018.

[18] Hamzeh Soltanali, Mehdi Khojastehpour, Jose Torres Farinha, "Measuring the production performance indicators for food processing industry," Measurement, 2020 (Article in Press), DOI: 10.1016/j.measurement.2020.108394

[19] Takao Matsumoto, Yijun Chen, Akihiro Nakatsuka, Qunzhi Wang, "Research on horizontal system model for food factories: A case study of process cheese manufacturer," International Journal of Production Economics, Vol. 226, pp. 107616, 2020.

[20]Linh N. K. Duong, Mohammed Al-Fadhli, Sandeep Jagtap, Farah Bader, Wayne Matindale, Mark Swainson, Andrea Paoli, "A review of robotics and autonomous system in the food industry: From the supply chains perspective," Trends in Food Science \& Technology, Vol. 14, 2020, pp. 355-364.

[21]Juan M Ponce, Arturo Aquino, Borja Millan, Jose M. Andujar, "Automatic Counting and Individual Size and Mass Estimation of Olive-Fruits Through Computer Vision Techniques," IEEE Access, Vol 7, pp. 59451, 2019.

[22] Bin Yu, Ping Zhan, Ming Lei, Fang Zhou, Peng Wang, "Food quality monitoring system based on smart contracts and evaluation model," IEEE Access, Vol. 8, pp. 12479, 2020.

[23]Jing Li, Zhenfeng Li, Ning Wang, G S V Raghavan, Yongsheng Pei, Chunfang Song, Guanyu Zhu, "Novel sensing technologies during the food drying process," Food Engineering Reviews, Vol. 12, pp. 121-148, 2020

[24] Jhonanttan Miranda, Pedro Ponce, Arturo Molina, Paul Wright, "Sensing, smart and sustainable technologies for Agri-Food 4.0," Computers in Industry, Vol. 108, pp. 21 36, 2020.

[25] Gurjeet Singh, P J Singh, V V Tyagi, A K Pandey, "Thermal and exergoeconomic analysis of a diary food processing plant," Journal of Thermal and Calorimetry, Vol. 136, pp. 1365-1382, 2019.
[26] Xinyu Chen, Tobias Voigt, "Implementation of the Manufacturing Execution System in the food and beverage industry," Journal of Food Engineering, Vol. 278, pp. 109932.

[27] Anthony Tri Tran, Q P Ha, Robert Hunjet, "Reliability enhancement with dependable model predictive control," ISA Transactions, Vol. 106, pp. 152-170, 2020.

[28]E. Theocharis, M. Papoutsidakis, A. Sort, C. Drosos, Experimentation on the Electromechanical Behavior of Automation Safety Buttons Applied to an Industrial PLC, WSEAS Transactions on Systems and Control, Vol. 15, pp. 733-742, 2020.

Dr. Vidya S. Rao completed her B.E in Electrical \& Electronics from Karnataka Regional Engineering College, Surathkal. She obtained her MTech degree from Manipal Academy of Higher Education and Pursued her $\mathrm{Ph}$.D. from Manipal Academy of Higher Education, Manipal. She is an IEEE member since 2017. She is an active member of ISSE (Indian Society of Systems for Science and Engineering)

K. Praveen Shenoy received the M.Tech in Control Systems Engineering in Mechatronics Engineering from Manipal Institute of Technology, Manipal, Karnataka, India in 2019. He is a member of the Indian Society of Technical Education (ISTE). His areas of research interests are robotics, automation, logic controllers, control theory, process control, and machine learning

Santhosh K V received his Bachelors and Master's from Visvesvaraya Technological University, Belgaum in 2004 and 2006. He received his Ph.D. from the National Institute of Technology Silchar in the year 2013. Dr. Santhosh KV is currently working as Associate Professor, in the Department of Instrumentation and Control Engineering, Manipal Institute of Technology, MAHE. Dr. Santhosh KV research interests are in the area of sensor fusion, smart sensors, and fault detection and isolation.

\section{Creative Commons Attribution License 4.0 (Attribution 4.0 International, CC BY 4.0)}

This article is published under the terms of the Creative Commons Attribution License 4.0 https://creativecommons.org/licenses/by/4.0/deed.en_US 